TTR

Traduction, terminologie, re?daction

\title{
Missionary Position: The Irony of Translational Activism in Colonial Orissa
}

\author{
Debendra K. Dash et Dipti R. Pattanaik
}

Volume 18, numéro 2, 2e semestre 2005

Traduction engagée

Translation and Social Activism

URI : https://id.erudit.org/iderudit/015766ar

DOI : https://doi.org/10.7202/015766ar

Aller au sommaire du numéro

Éditeur(s)

Association canadienne de traductologie

ISSN

0835-8443 (imprimé)

1708-2188 (numérique)

Découvrir la revue

Citer cet article

K. Dash, D. \& R. Pattanaik, D. (2005). Missionary Position: The Irony of Translational Activism in Colonial Orissa. TTR, 18(2), 89-113.

https://doi.org/10.7202/015766ar
Résumé de l'article

La position du missionnaire : le paradoxe de la traduction évangélisatrice dans l'Orissa colonial - La traduction est au coeur du projet missionnaire en Inde, ce plus particulièrement à la suite de la Réforme protestante. Dans leur lutte pour étendre leur influence, des missionnaires de diverses confessions non seulement traduisent les Écritures dans les langues locales, mais introduisent dans des sociétés traditionnelles plusieurs institutions modernes telles que l'école, l'hopital et l'imprimerie. Ces institutions, alliées à l'entreprise de traduction, constituent les outils de choix du prosélytisme. Le taux de succès est variable. Dans des régions comme l'Orissa, doté d'une forte tradition culturelle et religieuse, il est très faible. Même les éléments de modernité apportés par les missionnaires sont longtemps considérés avec méfiance, en raison de la conjoncture politique qui prévaut dans la région. L’activité missionnaire en Orissa au début du XIX ${ }^{\mathrm{e}}$ siècle est en effet associée à la domination coloniale. De plus, le sentiment de supériorité culturel et racial des missionnaires leur fait mépriser les conditions et la culture locales. Avec pour conséquence que leurs traductions, qui paraissent ridicules, sont aussitôt rejetées. Si l'Orissa dispose déjà d'une solide tradition en matière de culture littéraire et de traduction, le projet missionnaire contribue cependant à lui insuffler une nouvelle direction et un regain de dynamisme. Quoique les missionnaires aient largement échoué dans leur entreprise d'évangélisation, celle-ci a paradoxalement encouragé longtemps après leur passage le développement d'une culture littéraire et traductive synthétique en Orissa.

Mots-clés : subcolonialisme, codification culturelle, traduction évangélisatrice, langue $b h a \bar{s} \bar{a}$, culture orale.
Tous droits réservés ( $\mathrm{C}$ TTR: traduction, terminologie, rédaction — Les auteurs, Ce document est protégé par la loi sur le droit d’auteur. L’utilisation des 2007 services d'Érudit (y compris la reproduction) est assujettie à sa politique d'utilisation que vous pouvez consulter en ligne.

https://apropos.erudit.org/fr/usagers/politique-dutilisation/ 


\title{
Missionary Position: The Irony of Translational Activism in Colonial Orissa
}

\author{
Debendra K. Dash \\ Dipti R. Pattanaik
}

\section{Introduction}

Fakirmohan Senapati, a major Oriya writer of the late $19^{\text {th }}$ century describes an encounter with missionary translation in his autobiography. This encounter took place during his job as the Headmaster of a school set up by the missionaries. The Mission at that time was headed by one Reverend Miller who absolutely distrusted the Hindus. He only tolerated Fakirmohan, a Hindu, as the Headmaster because no Christian was available for the post. He used to express his disgust at such an arrangement by being unnecessarily abusive towards all the Hindu employees in that school. Even though he did not have the working knowledge of the culture within which he lived, including the knowledge of the difference between a Hindu festival and a Muslim festival, he presumed to undertake the translation of an English book into Oriya. The arrangement was that the translated text would be edited by Fakirmohan and then vetted by an Oriya missionary before going to the press for publication. Reverend Miller's Oriya rendering had followed the structure of English so closely that it appeared as an indiscriminate placing together of Oriya words without conveying any meaning. Fakirmohan made appropriate changes in the structure and took it for vetting to a native missionary of the Mission at Balasore who had Miller's trust. Unfortunately, the person was semi-literate and could only read portions of the Oriya Bible haltingly. The Oriya word 
which Fakirmohan had used to denote God's existence had a close phonetic resemblance with the Oriya word that denotes skeleton. The semi-literate Oriya missionary was alarmed by the presumed blasphemy by Fakirmohan and reported the matter to Reverend Miller. Since Mr. Miller had a congenital distrust for idolaters of all kinds he was terribly angry with Fakirmohan and his editing and apparently shelved the project. Miller's lack of cultural knowledge failed him as a translator.

There is a similar story of failure due to a missionary's lack of cultural knowledge while preaching at a remote Orissan village. The missionary, with characteristic arrogance, was holding forth in an artificial Oriya accent on the superiority of Christianity over the belief systems of the natives at the village square. After completing his theoretical exposition he picked on Krishna, one of the most popular characters of the Hindu pantheon and mythology, famous among other things for frolicking with sixteen thousand consorts. The Hindu devotees of Krishna interpreted the action as the lila or divine play symbolizing the spiritual bond between the devotee and the Godhead. The preacher, however, interpreted this as plain debauchery. To drive his point home, he brought out a picture of a naked baby Krishna holding his own penis and suggested that the thought of sex was paramount in Krishna's mind. The motley crowd that had gathered at the village square more out of curiosity for the strange manners and accent of the preacher apparently did not believe a word of what he was saying but went on tolerating him with a natural Oriya reverence for anything strange and different. They were also likely to lack the intellectual and rational resources at their command to counter the discourse of the preacher. But then one of the members in the audience who was apparently exposed to the outside world tried to reason with the preacher and said that he had not understood the true significance of the picture, as he was a Christian. The naked state of Krishna was actually a reaction to Jesus's prayer. Since the Christian God was always praying for more bounties with upraised arms and Krishna had already given away everything He had, He was offering His last possession. The crowd which was hitherto voiceless, suddenly began clapping and lauding the interpretation. Unable to marshal any other argument immediately, the preacher made a hasty retreat out of disgust while 
the crowd went home with a satisfying explanation / translation of the meaning of the picture.

Both stories narrated above lay bare the contempt with which the missionaries treated the non-Christian natives among whom they sought to spread their religion. They had realized the importance of interpretation/translation as a proselytizing tool, but at the same time they were almost blind to the role of language and culture as important ingredients in the translational process. In the first instance, Fakirmohan's Reverend Miller gave greater credence to religious loyalty than to linguistic expertise in the process of translation. For him, language was just a passive instrument which could be moulded at will to carry the burden of the 'superior' ideas and world-view under his command. It was never a cultural marker, so that one need not understand the dynamic of the culture to which a language belonged in order to be able to use that language for translational purposes.

The hollowness of these assumptions is all the more glaring in the second story. The preacher concerned is absolutely ignorant of the social context into which he presumes to pour his superior reason. The assurance of the supposedly superior faith, like the assurance of the power of the colonizer which Rev. Miller possessed, leads the preacher into a mistaken belief that he is inaugurating history in an apparently unhistorical terrain through his knowledge of theology, religion and social-cultural life. The native like Yeats's Leda is a mere passive receptacle for this masculine, reasonable, powerful and valid knowledge. The native's position, of course, was subservient in political terms to Rev. Miller and the preacher; but it was not the total denial of agency on the part of the native as was presumed by the latter. It was a different kind of agency which the preacher failed to see. The native's agency becomes visible in the terms set down by the preacher after his world-view and faith are infused with the new set of ideas propagated by the preacher. The calibanesque thwarting of the missionary design in the story by the native with the help of the tactic taught by the preacher himself to protect the sanctity of his own faith and the sacredness of the structure of his unconscious is the preamble to the larger story of the translational activism of the missionaries in colonial Orissa. 
Though in the isolated cases described in the above stories the activism of the missionaries failed-Rev. Miller, in fact, was removed from Orissa by the American Mission under whose aegis he worked, because of several criminal charges against him by the natives-the presence of the missionaries and their intervention in the translational process continued unabated for almost two hundred years of Orissan history. It would however be wrong to assume that Orissa or Oriya language received any special attention from the missionaries. In fact, the missionary intervention can be detected in all the Indian bhasa languages during the British occupation of the country. And it would be safe to presume that the attitude of such intervention might have been similar to the one demonstrated in the stories cited above. However, as far as our knowledge goes, there has not been any detailed study in India of the ideology of such intervention from the perspective of translational theory. Saurabh Dube's essay in Economic and Political Weekly entitled "Conversion to Translation: Colonial Registers of a Vernacular Christianity" discusses issues of colonial conversion and questions of vernacular translation, but it deals more with sociological implications of missionary writings in the Chhatisgarh area rather than with the ideology of translation. Though he has taken Vicente Rafael's seminal work Contracting Colonialism as his model, he has not analyzed the various stages of missionary engagement in the translational process the way Rafael has in the case of the Tagalog language of the Philippines. Most other works like those of De (1919), Das (1946), Mishra (1978) are studies of influence. They have analyzed how the writings of the missionaries have shaped modern literatures, specifically prose in respective languages. They have tried to assess the literary and aesthetic merit of the works objectively; but they are almost silent about the ideological and linguistic implications of the intervention of the missionaries. The present paper seeks to map the translation activities of the missionaries in the Oriya language by historicizing the entire phenomenon, analyzing the ideological underpinnings, identifying the methodology that was used, recording its impact on the Oriya episteme in general and on the formation of Oriya nationalistic discourse in particular. 


\section{Colonial Power and Proselytizing Mission}

The arrogance of the missionaries represented in the stories above highlights among other things, the complex relationship between colonial power and proselytizing mission. Of course, Christian missionary presence in India was not always aided by colonial hegemony. Dr. Rajendra Prasad, the first President of India, rightly reminds us that St. Thomas came to the Kerala coast of India to spread Christianity in the $1^{\text {st }}$ century A.D., much before the European nations had embraced the religion (Soreng, 1998, p. 31). But the influence and spread of the initial missionary activity remained confined to the regional level for several centuries. Up to the $15^{\text {th }}$ century, at least six missionaries had come to India to preach Christianity, but most of them had failed either due to popular resistance, violence, or indifference of the people. Thus it can be safely assumed that the influence of missionaries was rather limited and proselytizing activities sporadic throughout the entire medieval period.

The activity of the missionaries gained momentum after the European Renaissance and the discovery of the sea route to the subcontinent. The expeditionists ostensibly were inspired by the myths of a fabulous India spawned by medieval European writers. Further, there was a myth circulating among European Christians regarding a Christian Kingdom beyond Persia ruled by the legendary king John. Smarting from the humiliation of the fall of Constantinople, the Christians of Europe were trying to establish links with this powerful mythical kingdom in order to destroy the Muslim dominance. The purpose of proselytization was also implicated in the discovery of the sea route; for the Portuguese sailor Vasco da Gama who sailed across the cape of Good Hope for the first time to reach India had two aims, namely to trade in spices and enable Christian missionaries to take up proselytizing activities in the Indian subcontinent. At first, Portuguese and subsequently Dutch missions were established in the $16^{\text {th }}$ century. The aggressive and violent proselytization of the Portuguese missions created a social havoc in the then Goa and the western coastal areas of India. Because of this, their acceptability in the rest of the country became very restricted. Due to the liberal policies of the Mughal King Akbar some missionaries had gained access to northern India at least for 
theological debates. Only a limited number of missionaries aided by mercenary soldiers and merchants were able to travel to some part of Northern and Eastern India towards the first part of the $17^{\text {th }}$ century. These missions of Catholic denomination were soon overtaken by the Protestant churches because of the latter's aggressive and more organized proselytizing activities.

The Protestant Missions of various denominations were galvanized into more organized missionary activities in the $18^{\text {th }}$ century due to the Moravian movement in Germany followed by the Methodist movement in England. Both movements had in fact started independently around the same time, i.e., the Moravian in 1727 and the Methodist in 1729. The Moravians were the first Protestants to proclaim world evangelization as their mission. They led a simple and frugal life and preached their doctrines keeping in touch with the life of the common people. They also extended their activities among primitive races and started preaching in extremely hostile terrains. The Methodists came in contact with the Moravians in 1739 after the latter extended their activity to England in 1735. The religious revival that ensued emphasized the salvation of not only the neglected people in England, but the salvation of even the nonChristians all around the globe. The revivalism was based on the Moravian doctrine that "conversion comes as a sudden personal assurance of salvation bringing new birth and dominion over sin" (Trevelyan, 1945). This doctrinal assurance of spiritual fruit for the labour of conversion might have inspired the proliferation of missionary activities. The Protestants in general and the Methodists in particular were convinced of the superiority of their religion and world-view and the necessity of indoctrinating the heathens with this superior faith.

This religious revivalism also succeeded in transforming the English society in particular and the character of Protestant evangelization in general in various other ways. The movement had largely taken root among the English middle class consisting of traders and professionals. These people had not only a deep concern for the poor, ignorant and neglected people, but also wanted to compensate their lot with charity. Their charity consisted of "building churches, establishing churches, erecting hospitals and distributing religious tracts" (Sengupta, 1971, p. 8). This notion of 
charity was of course already there as appears from the code among Protestant denominations of the first Mission to India in 1706 by Frederick IV of Denmark. The code holds that:

a) There should be a school alongside the churches. The Christians should be able to read the words of God, therefore, every child should be taught to read.

b) If the word of God is indispensable for a Christian, then the Bible which is the work of God should be made available to every Christian in his native tongue.

c) The words of God should be preached to the people after studying their minds properly.

d) This process should culminate in transforming the personal views of every individual.

e) Indian missionary societies should be entrusted with the task of superintending the Indian Christian communities. (O’Mahony, 1974, p. 299)

But what the Dutch Mission probably lacked was this faith in personal salvation as the reward of missionary activity. The belief in the reward gave the Methodist Movement and the notion of charity a more dynamic character and a sense of zeal for proselytization hitherto unseen.

This dynamic character and sense of zeal underpinned the efforts of a missionary like William Carey (1761-1834) who came to Bengal in 1793 and inaugurated a most fertile phase of missionary and translational activity in Eastern India. Carey had to undergo acute poverty, destitution and harassments while pursuing his activity. He was not allowed to set up a mission in Calcutta since there was an official ban on missionary activities within the company territory. Carey learnt the local Bengali language against heavy odds. When Fort William College was established in 1800 he was persuaded to take up the position of Professor of Bengali, Sanskrit and Marathi, which he accepted in 1801 after some deliberations. He probably accepted this secular assignment to further missionary activities from the vantage position of an administrative authority within Calcutta, the headquarters of the East India Company. He might also have had a hand in influencing the company administration to allow missionary activities in its territory. His strong views on the matter 
can be gleaned from a correspondence where he mentions, "no Christian Government that I know of has prohibited attempts to spread Christianity" (Sengupta, 1971, p. 51). But before that decision was taken in 1813, Carey had already been associated with a Mission established in 1799 by John Marshman and William Ward at Serampore, a place under Danish control. It was there that Carey established the printing press he had bought. The Mission Press published Carey's Bengali translation of the Bible, which had been completed in 1796. This Serampore Mission and Carey's translation of the Bible into Bengali had a far-reaching impact on the missionary and translation activities in Orissa.

The coastal area of present day Orissa was occupied by the colonial administration in 1803. But sporadic missionary activities had already started in other Oriya-speaking tracts from the $16^{\text {th }}$ century onwards. On June 24, 1806 a traveling missionary, Dr. Buchanan, in his tent near the Chilika Lake had a dream in which he foresaw that the entire land would be turned over to Christ in the near future. After returning to England he influenced public opinion in favour of organized missionary activity in Orissa. By 1822, all Oriyaspeaking tracts had been gradually won over by the company and around the same time, i.e. on 12 February 1822, missionaries like Bampton and Peggs reached Orissa with the specific purpose of spreading Christianity among the Oriyas. As has already been hinted, by 1813 the British Parliament through legislation had allowed the missionaries ostensibly to undertake educational activity in company territory. Since then the company administration had been encouraging the appointment of bishops in Calcutta. The Missionary Societies formed in Britain sent their representatives to various parts of India. After Bampton and Peggs in 1822, Charles Lacey came to Orissa in 1823. Amos Sutton followed suit on 11 March, 1825, and Nois and Phillips, in 1835.

It should be clarified here that the missionaries of Orissa were not a homogeneous group. They belonged to different Protestant denominations and groups like General Baptist Mission Society, American Free Will Baptists, Particular Baptist Missionary Society, Evangelical Missionary Society and German Evangelical Lutheran Missionaries, etc. But after operating in Bengal and Orissa they seem to have found a commonality of interest as evidenced by 
the letter of Eli Noyes of A.F.B.M. to James Peggs of General Baptist Mission in 1837, "our interest is the same with your missionaries; our sentiments are one; our cause is one and we are one" (Swaro, 1990, p. 3). Thus in effect in certain spheres like the establishment of schools, translation, and health care, the activism of the missionaries in Orissa, like Amos Sutton, was a continuation of the activities of missionaries like William Carey in Bengal.

The difference between the activity in Orissa and the rest of the country however was due to the peculiar demographic composition of Orissa. Firstly, the Muslim presence in the state was almost negligible. Since the missionaries perceived Islam as a competing ideology and in fact many lower caste Hindus had been lured into the Islamic fold in the rest of the country, the thin presence of Islam in Orissa was quite an alluring possibility for Christian missionaries. Moreover, Catholic Missions settled elsewhere in the country were virtually absent from Orissa till the 1850s. The Catholic missionaries had a tendency to latinize the scripts instead of emphasizing translation activities. Indeed one can come across several works in Bhasa languages in Roman scripts in places where there was sizable Catholic presence. Such efforts are totally absent in Oriya. Another difference one encounters in the Orissan situation relates to institutions of modernity. In many parts of the country, including Bengal, institutions like schools imparting modern education and the printing press were established both by secular organisations and by missionaries. Secular philanthropists like David Hare and teachers like Drummond who were not associated with any mission had started academies in Bengal, much before the missionaries established their schools. Through English education Bengal was exposed to different trends of civilization-humanistic, scientific and Christian. Thus English education itself gave important tools to the Bengalis to combat the progress of doctrinal Christianity (Das, 1974, p. 153). But the occupation of Orissa by the East India Company and the advent of missionaries in Orissa were almost simultaneous. Thus in the popular perception missionary activities were conflated with colonial hegemony. In the absence of a tradition of secular education, it was the missionaries who mediated modernity in Orissa through the school system and the printing press. But unlike in other parts of the country, the missionaries had to undertake special efforts in Orissa to popularize education, the printed word and 
by extension the missionary activity which we shall discuss further in a different context.

\section{Bengal and Orissa}

As hinted in the earlier section, the Bengali translation of the Bible by William Carey served as the foundation for all subsequent translations in Bengali and Oriya languages. Up to the establishment of Orissa Mission Press in Cuttack in 1837, all translations into Oriya were carried out at Serampore Mission Press under the aegis of William Carey. The Serampore Press was established by Carey, on January 10, 1800. After the establishment of the Press, Carey undertook the carving out of printing letters in fifteen different Indian languages including Oriya, under the supervision of Panchanan Karmakar. The preparation of the letter font for the printing press was a part of Carey's plan to publish the translated versions of the Bible in several languages. Though his purpose ostensibly was to disseminate Christian theology through translation, he did not hesitate to request the assistance of people belonging to other religions in both logistics and intellectual input, an attitude quite different from the attitude of Rev. Miller mentioned in the first section of this essay. For example, he had employed people belonging to various linguistic groups and religious denominations in the project of Bible translation under his supervision. Subsequently, when he joined Fort William College as a Professor, he also requested the assistance of his colleagues, the Hindu pundits, in the translated works to be published from his Press.

According to various reports, Carey's translational effort resulted in the publication of the Bible in several Bhasa languages including Oriya. In fact the work on the translation of the Oriya Bible had already started in 1800. Between 1800 and 1810 Carey had sent four missionaries named Krishna Pal, Sevak Ram, John Peter and Krishna Das along with the Oriya and Bengali versions of the Bible for preaching purposes. Though the proselytizing efforts were rather unsuccessful, Carey and his associates were never deterred in their translational efforts. We will analyze the consequences of such efforts later but suffice it to mention that the effort of Carey is an isolated instance of dedication to his mission. He continued to send missionaries along with vernacular versions of religious texts when 
the East India Company allowed missionary activities in its territory after 1813. In Orissa, however, the missionary activities thawed during the Paika movement between 1816 and 1820 due to the restriction imposed by the Company.

It is worth mentioning here that the missionaries sent by Carey had travelled mainly within the coastal districts of Orissa like Cuttack, Puri and Balasore along with the printed Oriya texts. Though there were missions in the Southern and Western parts of Orissa they had not undertaken any translational activity. Thus in the long run the identification of the Oriya people of the coastal districts with the printed Oriya texts was much closer than that of the people of other parts of the state. The people of these districts were exposed to modern education and reading practices much earlier than inhabitants of other parts of Orissa due to Carey's efforts.

The tradition Carey inaugurated continued unabated by subsequent missionaries who, unlike him, made Orissa their field of work during the $19^{\text {th }}$ century. A vast portion of the translated material published from Serampore Press and then from Orissa Mission Press at Cuttack has since been lost to the general reading public. The body of work that is still available can be found in Ravenshaw College Library at Cuttack, William Carey Library at Serampore, Utkal Sahitya Samaj Library at Cuttack, and Christian Paramartha Vidyalaya Library at Cuttack. But an idea of the total body of work can be reconstructed from various catalogues provided by researchers. Moreover, there are some history books on missionary works written by the missionaries themselves such as:

\section{a) History of the General Baptist Mission by James Peggs in 1846 \\ b) Narrative of the Mission to Orissa by Amos Sutton in 1833 \\ c) Orissa and its Evangelization by Amos Sutton in 1850}

These can give us a fair idea of the volume of their work. There are some contemporary reports which also carry a record of the published material.

According to one such report, though the work on Oriya translation of the Bible was started in 1800, its publication was 
delayed for a long time due to several reasons. First of all there was difficulty in translating the text into Oriya. Carey and his associates then decided to employ the services of an Oriya Pundit, Pooroosh Ram. While the work on the Bible was in progress, a portion of the third part of the Bible was published in 1807 using the Greek original. The final Oriya version of the New Testament saw the light of day in 1809. Within another ten years, all the parts of the Bible, Psalms, Hagiography, Life of Saints were published from Serampore Mission Press using Bengali as the filter language. In 1811, a Book of Hymns written originally in Bengali had also been translated to Oriya and published subsequently. With the exception of one secular book titled Vocabulary written by Mohunpersaud Takoor which was published in the same year and was dedicated to William Carey, the long history of publication from Serampore Press and Baptist Mission Press at Calcutta till 1830 includes only religious books and tracts.

Once missionaries like Amos Sutton, Peggs, Lacey and others consolidated their position in Orissa, the character of translational activity changed. They started writing and publishing several secular texts including grammar books and dictionaries. The volume of writing was so large that it necessitated the establishment of a Press in Orissa. With the establishment of the Orissa Mission Press at Cuttack in 1837, their publication activity, which included both religious and secular texts, was bolstered further. The missionary translation activity in Orissa can be divided broadly into three phases. The first phase can rightly be called the Carey-phase and extends from 1801 to 1822 . The Oriya translated texts and tracts produced during this period were published from the Mission Press, Serampore and were directly supervised by William Carey and his associates. In the second phase which lasted from 1822 to 1836, missionaries like Charles Lacey and Amos Sutton who were stationed at Orissa took up translation activity on a grand scale. But their translations were still published from the Mission Press at Serampore. However, these translations, due to the locational advantage of the translators, were closer to the Oriya language and culture than the translations of the Carey-phase. After the establishment of the Mission Press at Cuttack, the works of Lacey, Sutton and Stubbins were published from Cuttack itself. In January 8, 1852, and in August 17, 1854, both Charles Lacey and Amos Sutton died, and in 1865 Stubbins returned to England. After 1865 some 
local presses were established by the educated Oriya elites, and they also started publishing newspapers and journals. Their involvement with print culture and translational activity opened a new phase in the cultural history of Orissa. This phase is characterized by the simultaneous existence of a variety of translational trends, i.e. the trend generated by foreign missionaries, the involvement of native Oriyas converted to Christianity and the translations by the elite Oriyas educated in the modern school system. Thus, after 1865, the field of translation became a very complex and a highly contested territory and had a different trajectory of growth. Our discussion, however, is confined to the first three phases mentioned above.

\section{From Bengal to Orissa}

The missionary translation of the first two phases can be broadly divided in two categories, namely, the translation of secular texts and the translation of religious texts. The secular texts included translated texts of Indian literature, textbooks for school curricula, government regulations and circulars, whereas the religious texts comprised translations of English and Bengali tracts, Christian literary allegories and the translation of the Bible. When the East India Company created the post of Oriya Translator, it was offered to Amos Sutton, one of the missionaries actively involved in the translation activity. Thus, in Orissa, the missionaries were legitimized as mediators between the administration and native Oriyas. The translational activity, instead of becoming a mediator between two languages and cultures, became an instrument of hegemony of both the State and the Church. During the third phase, after the establishment of the Mission Press at Cuttack, the perpetuation of this dual hegemony became the chief purpose of translation activity. Under the guise of the production of secular texts and school textbooks, the missionaries were able to enlarge their sphere of activities. In the process they were also able to undermine the avowed secular character of the Company administration. Though the ideological imperative behind the three phases of translational activity were varied, the methodology of translation fashioned by William Carey was continued throughout with minor changes. Carey's method can be deciphered from a letter he wrote to his friend Mr. Fuller :

... we never print any translation till every word has been revised and rerevised. Whatever helps we employ, I have never yet 
suffered a single word, or a single mode of construction to pass without examining it and seeing through it, I read every proofsheet twice or thrice myself, and correct every letter with my own hand. Brother Marshman or I compare with the Greek or Hebrew, and brother Ward reads every sheet. Three of the translations, Bengali, Hindustani and Sanskrit, I translate with my own hand; ... whatever helps I use, I commit my judgment to none of them. Indeed, I have never yet thought anything perfect that I have done. I have no scruple however, in saying that I believed every translation that we have printed to be a good one. (Myeres, 1892, p. 284)

From Carey's letter the mechanical nature of the model is transparent. Instead of being a creative enterprise, translation became a dehumanized instrument in the hands of the missionaries. Even missionary historians like Richter have found these translations, specifically the translations of the Bible and the tracts, "inaccurate in language and imperfect in idiom” (Sengupta, 1971, p. 92). But Richter, too, has not analyzed the problem of position in missionary translation adequately. The problem is primarily that of the cultural baggage of language which the radically iconic translation fails to see. This problem was compounded by the translators' lack of competence in the target language. The missionaries were not only incompetent in the target language, they also subscribed to the notion of the inequity of language because of their position in the power structure. Often their collaborators were either mercenaries or had very little literary training to carry out such activities. In the case of Orissa, the problem got more accentuated because they used Bengali as an intermediary language for translation. Because of the unconscious importance they attached to Bengali as a language, they were less rigorous in their attention to Oriya. Such lack of respect for the target language was integral to the colonial/missionary ideology. Translation under such a dispensation was like a weapon of war against the heathens to deliver them from their own sin and ignorance. Out of several brochures / manuals on the processes and strategies of translation into vernaculars published by the Mission Press at Serampore, at least four that have been cited by contemporary scholars reinforce this idea : "Fourth Report of Operations in Translating, Printing and Circulating the Sacred Scriptures in the languages of India," "Addren Respecting Translations," 1808, by William Carey, $8^{\text {th }}$ Memoir: "Respecting the Translation and Edition 
of Sacred Scriptures," December 1822, and $10^{\text {th }}$ Memoir: "Respecting the Translation of Sacred Scriptures into Oriental Languages.” In the first manual (Fourth Report) Marshman declares: “... cost what it may, in men and money, in prayers and labours, India must be won to Christ.” Marshman's aggressive proselytizing statement in a translation manual shows the deep affinity between preaching and translation mentioned earlier. Translation, instead of becoming a negotiation between cultures and languages, became a veritable warfare in the hands of missionaries. Like the conquistadors, the missionaries prepared elaborate strategies, appointed foot-soldiers in the form of menials from among the natives, used their technological might in the form of the printing press in order to spread their wares easily, in large quantity and rapidly. In the process, they ignored the cultural specificity of the Oriya language and the need to master linguistic nuances. They, of course, tried their hands at lexicography and compilation of grammar, as the European models of translation had already recognized these activities as important tools, but they used them as tools of warfare against the 'ignorant,' 'savage' and 'heathen natives.' Instead of developing these tools from the native soil and episteme they ended up grafting the Latin grammar and lexicographical models on an inhospitable Oriya soil. The ideology of colonial/racial supremacy that informed the missionary translational activism prevented missionaries from seeing the fact that Latin models might have worked for European cognate languages, but might prove superfluous in case of a language like Oriya. One concrete example from the Lexicon prepared by Amos Sutton is worth citing here. In the case of the Oriya word "Ishwara" which designated the Hindu deity Shiva, Sutton imposed the Christian idea of "God." In fact, the entire translational project was based on the wrong assumption that the missionaries were handing down "Knowledge" to an "ignorant" mass in the same way that the colonizers presumed to create history in an ahistorical colonized space. Thus "knowledge" in whatever form, be it in mutilated and monstrous linguistic formulation, would be of great worth for the ignorant masses. This arrogance made them blind even to the European/English models, which had been developed by that time. In Europe various translational models had evolved after the Renaissance following the translation of the Bible and the Greek, Latin and secular canonical texts. Dryden, both a translator himself and a theoretician, following some of the injunctions of Horace, had 
formulated that "No man is capable of translating poetry, who, besides a genius to that art, is not a master both of his author's language, and of his own; nor must we understand the language only of the poet, but his particular turn of thoughts and expression, which are the characters that distinguish, and as it were individuate him from all other writers” (Steiner, 1992, p. 71). It is needless to mention that, in their haste to hand down 'virtue' and 'knowledge' to the deprived native subjects, the missionaries conveniently ignored such prescriptions which they might not have dared to do in case of any European language. They even ignored the book by Alexandar Fraser Tytler which had been published in 1791, a few years before the missionaries started their translational activities in an organized manner. This book narrativized the English translational practice of Chapman, Dryden and George Campbell and suggested several translational norms. The contempt for the target language demonstrated by the missionaries might also have been partly informed by the Protestant ideology itself. A few texts produced by Catholics have more empathy for the target language and culture. For Catholic missionaries did not align themselves with State machinery and the nationalist project which was integral to Protestant ideology. Catholic missionaries adopted the life-style and the culture of the natives in order to spread the gospel of Christ. Therefore the Catholic Bhagabata written by a native converted to Catholic Christianity is closer to Oriya literary form and substance. Since most of the missionaries involved in translation activity in Orissa belonged to the Protestant faith, the idea of a language without cultural baggage informed their consciousness. For them, as Vicente Rafael observes, "what gives language its gravity is ultimately the message it conveys" (1988, p. 25). They were more interested in conveying the message of Christ which was their primary purpose, and overlooked the necessity of honing the instrument of language. Thus missionary translation was always fraught with a kind of 'inequality' and 'inequity' of languages described by Saurabh Dube:

Such inequality also implies inequity, the two together constituting a resource and forming a conduit for the inscription and re-insertion of asymmetries of languages and idioms, knowledge and power in the name of neutral science and in the guise of authoritative translation. (2004, p. 164) 
This inequality between languages reinforced the old hierarchies between Sanskrit and Oriya in operation during earlier times. In two earlier essays, "Translation and Social Praxis in Ancient and Medieval India" and "Translating Medieval Orissa," we have demonstrated how a need-based translation had levelled down the old hierarchies and had created a more democratic translational space in the Oriya episteme. The power-driven translation of the missionaries appropriated the space left by the Brahminical culture and the Sanskrit language and placed European/British culture and the English language in the dominant position vis-à-vis the Oriya language and culture.

\section{Impact of the Translational Activism of the Missionaries}

The translational activism of the missionaries failed to have much impact initially except in converting a few Hindus to the Christian fold. But the process they unleashed had a far-reaching impact shaping the future course of translational and literary discourse in Orissa.

First of all, the missionaries set up schools in the British model to create a captive readership for their translations and by extension future converts to Christianity. The British mode of education inevitably exposed the newly literate to all the liberalizing influences of European thought through printed books, which were gradually available on the Indian market. From a dominantly oral culture, the society gradually shifted to a print culture. In order to make the print medium more acceptable to the general public-for some of the already literate elite were suspicious of the print medium and often got printed books transcribed in palm leaf manuscripts to be able to read them--they initiated translation and publication of popular, secular texts such as Batrisha Singhasana.

Secondly, this print culture played a vital role in shaping an identity discourse around Oriya language and Jagannath Cult. In Imagined Communities Benedict Anderson demonstrates how print capitalism and Protestant ideology shaped the national communities in Europe. A similar process was unleashed by the intervention of missionaries, both in their attempt to unite the Oriya speaking people under a print culture and setting up their difference from others by 
attacking the local deity Lord Jagannath viciously, in their tracts translated from English or Bengali originals. (For further discussion on the subject see Dash, G. N.)

The missionaries also popularized the prose form in their translations and religious tracts. The genre of prose was already available in Oriya literature but it was not as popular or widespread because it could not be circulated by the singing mendicants, and other instruments of popular culture like pala, etc. Once the circulation of prose became widespread through the print medium used by missionary translators, Oriya writers of the era became aware of its power. Soon these writers started experimenting with the form in an extensive way. The accounts of the converts became the model for the subsequent modern short stories in Oriya.

Further, iconic translation and faithfulness to the original became the translational norm in a significant way. We are aware of the importance Puritans and other Protestant Christians attached to faithfulness in the translational process. The same anxiety for faithfulness was transmitted through missionary contact. The subsequent endotropic and exotropic translations in Oriya bore the impact of the missionary experience.

Lexicography and formulation of grammar are the other two important contributions of missionaries to the Oriya episteme. These were considered important tools for the missionaries to learn the native language and undertake translation projects. Subsequently linguists like Beames and other colonial administrators contributed to this very complex and specialized field. Such attention it must be remembered was earlier reserved only for Sanskrit.

Missionary translational activism also introduced the European notion of intellectual property to the Oriya episteme. The norm of strict faithfulness employed in iconic translation is based on notions of originality and authorship. The dominant Oriya translational praxis subscribed to creative translation, which meant mutilation, reorganization and extension of the so-called "original" text in order to make it closer to local knowledge and taste. The hierarchy that privileged the original text and the author above the translated text and the translator was subverted in the dominant Oriya 
translational praxis. The texts, as it were, belonged to the public domain and the translator was credited with as much creativity as the "original” creator. Missionary translational activism introduced the hierarchy which relegated translation to a subservient position vis-àvis creative writing and originals.

Earlier, the difference between the two cognate languages, Bengali and Oriya, was very wide, and both of them were on equal footing. After the missionaries started translations into Oriya through the filter language of Bengali, an intellectual dependence on Bengali was initiated. At one level this generated a language-based identity discourse among the Oriyas and, at another level, there was a protracted intellectual subcolonialism in Orissa involving Bengali language and literature.

Apart from subnationalist feelings, a strain of pan-Indian Hindu nationalism also took roots in Orissan soil due to missionary activism. In The Shadow of the Cross, S.K. Das provides the reason for such a consolidation:

The issue of racial superiority slowly clouded the whole atmosphere. The area of controversy was enlarged. The Indian intellectual slowly realized that Christianity was linked up with European civilization - it was linked up with the power that ruled and this attitude helped the growth of nationalism, which in its first phase was religious nationalism. (1974, p. 37)

In consequence, there was a resurgence of Brahminical Hindu ideology and Sanskrit scholarship. Sanskrit texts became very popular and Sanskrit grammar and language became the model for Oriya grammar and lexicography. Simultaneously, English as a language assumed the hegemonic status vis-à-vis Oriya, a status which Sanskrit enjoyed earlier.

Finally, after the initiative of missionaries, a tradition of translation of secular literary texts was initiated. European knowledge, literary text, etc. served as the foundation for modern Oriya literature.

Thus, the activism of missionaries in the field of translation had a long term impact rather than an immediate effect. The 
immediate purpose of proselytization, eradication of superstition from the society, alleviation of poverty and education of the natives had a limited success. But ironically this effort consolidated the study of Oriya language, literature and national identity and an increased religious and cultural allegiance, which were against the wishes of the missionaries. It would be fruitful to recall here the anecdotes described in the beginning of the essay. In both of them the arrogance of a supposedly superior worldview has been ridiculed by the native and at the same time the so-called inferior native has assimilatively appropriated the "superior world-view" and has taken a vantage position from which he can reject the missionary position outwardly.

\section{Ispat College Utkal University}

\section{References}

ANDERSON, Benedict (1983). Imagined Communities. London, Verso.

BANDYOPADHYA, Asit K. (1965 [1959]). Unabimsa SatabdirPrathamardha O Bangla Sahitya. Calcutta, Bookland Pvt. Ltd.

BARNSTONE, Willis (1993). The Poetics of Translation. New Haven, Yale University Press.

COHN, Bernard S. (1997). Colonialism and Its Forms of Knowledge. Delhi, Oxford University Press.

DAS, Sajani K. (1975 [1946]). Bangla Gadyasahityer Itihas. Calcutta, Chirayat Prakasan Pvt. Ltd.

DAS, Sisir K. (1974). The Shadow of the Cross. New Delhi, Munshiram Manoharlal, Pvt. Ltd.

DASH, Debendra K., ed. (2002). Fakiramohan Granthabali. Vol. П, Cuttack, Grantha Mandir. 
DASH, Debendra K. \& PATTANAIK, Dipti. R. (2005). "Translation and Social Praxis in Ancient and Medieval India." In Translation. Delhi, Pencraft.

DASH, Gauranga C. (1989). “Padrinka Krutitwa Kalana.” Esana, 19. Cuttack, Odiya Gabesana Parishad.

DASH, Gaganendra N. (1978). "Jagannath and Oriya Nationalism." The Cult of Jagannath and Regional Tradition of Orissa. A. Eschmann et al, eds. New Delhi, Manohar.

- (1983). Odia Bhasacharchar Parampara. Cuttack, Odia Gabesana Parisad.

DE, Sushil K. (1962 [1919]). Bengali Literature in the Nineteenth Century. Calcutta, Firma KL Mukhopadhyay.

DUBE, Saurabh (2004). "Conversion to Translation: Colonial Registers of a Vernacular Christianity." Economic and Political Weekly. Vol: XXXIX No. 2, (January 10), New Delhi.

KAR, Bauri B. \& PANDA, Ashwini K., eds. (2003). Ammas Satan Rachanabali. Cuttack, Friends Publishers.

MISHRA, Binapani (1986). Odisare Khristadharma O Odia Sahityare Tar Prabhab. Cuttack, Prachi Gabesana Parishad.

MISHRA, Srinibas (1978). Adhunik Odiya Gadya Sahitya. Cuttack, Vidyapuri.

MOHANTY, Bansidhar (1955). Sahitya O Samskruti. Cuttack, Janasakti Pustakalay.

MOHAPATRA, Sitaram (1988). Unabimsa Satabdire Odia Sahityaku Khristian, Misanarimananka Abadan, Cuttack, Utkal Khristiya Sahitya Borda.

MYERS, John B., ed. (1892). The Century Volume of the Baptist Missionary Society (1792-1892). London. 
NANDY, Ashis (1983). The Intimate Enemy. Delhi, Oxford University Press.

NAREGAL, Veena (1999). "Colonial Bilingualism and Hierarchies of language and Power." Delhi, Economic and Political Weekly (December 4, 1999).

NIRANJANA, Tejaswini (1992). Siting Translation. Berkely, Los Angeles, U. of California Press.

O’MAHONY, Christopher (1974). Church History-A Summary. Vol. 2 Always, Pontificial Institute of Theology and Philosophy.

PATRA, Praphula K. (2004 [1942]). Odisare Baptist Misanari Sosaitir Karya Ebam Khristiya Mandali Sthapanar Itihas: 1882-1942. Cuttack, Utkal Khristiya Sahitya Parisad.

PEGGS, James (1846). History of the General Baptist Mission. Cuttack, Mission Press.

PRAHARAJ, Bijayalaxmi (2003). Religious Movements of Orissa during the $19^{\text {th }}$ Century. Cuttack, Arya Prakashan.

RAFAEL, Vicente L. (1988). Contracting Colonialism. Ithaca, Cornell University Press.

SAMANTARAY, Natabar (1983). Adhunik Odia Sahitya Bikasar Prusthabhumi. Bhubaneswar, Published by the Author.

- (1979 [1964]). Odia Sahityar Itihas (1803-1920). Bhubaneswar, Published by the Author.

SEN, Priya R. (1947). Modern Oriya Literature. Calcutta, Published by the Author.

SENGUPTA, Kanti P. (1971). The Christian Missionaries in Bengal (1793-1833). Calcutta, Firma K.L. Mukhopadhyay. 
SINGH, Jayananda (1996 [1914]). Odisare Khrist-Dharmoday O Ketek Adya Khristiananka Jibani. Cuttack, Utkal Khristian Sahitya Bord.

SORENG, Ignatius (1998). Odisare O Odia Sahityare Khristadhrma. Berhampur, Deepti Prasarini.

STEINER, George (1992). After Babel. Oxford, New York, OUP.

STEINER, Thomas R. (1975). English Translation Theory (16501800). Assen, Van Gorcum.

SWARO, Dasarathi (1990). The Christian Missionaries in Orissa. Calcutta, Punthi Pustak.

TREVELYAN, George M. (1945 [1929]). History of England. London, Longmans, Green \& Co.

VISWANATHAN, Gauri (1990 [1989]). Masks of Conquest. London, Faber and Faber.

— (1998) . Outside the Fold. Delhi, Oxford University Press.

ABSTRACT: Missionary Position: The Irony of Translational Activism in Colonial Orissa - Translating was crucial to the missionary project everywhere, especially after the Protestant Reformation. In their competition to expand their reach, various denominations of missionaries not only translated the Scriptures into the various local languages where they went, but also mediated various modern institutions like the school system, health-care and print-technology in those traditional societies. These institutions and the activity of translation were often the means to achieve the ultimate goal of proselytization. Their rate of success in achieving their goal in different places varied for several reasons. In places like Orissa where there was a deep-rooted cultural and religious tradition, their rate of success was very low. Even the forces of modernity they tried to mediate were regarded with suspicion for a long time on account of the peculiar political condition prevalent in Orissa at that time. Their activism in Orissa during the early part of $19^{\text {th }}$ century was conflated with colonial hegemony. Moreover, the racial and 
cultural pride of missionaries prevented them from respecting the local condition and culture. Therefore, the translations they undertook were perceived as ridiculous and were summarily rejected. Orissa already had a long literary-cultural and translatory practice. The missionary challenge, however, helped in reorienting and galvanizing this tradition in a specific way. Although the missionaries largely failed in achieving their primary goal, their activism ironically helped in the growth of a new synthetic translational and literary culture in Orissa, long after their influence had waned.

\section{RÉSUMÉ : La position du missionnaire : le paradoxe de la traduction évangélisatrice dans l'Orissa colonial - La traduction} est au cœur du projet missionnaire en Inde, ce plus particulièrement à la suite de la Réforme protestante. Dans leur lutte pour étendre leur influence, des missionnaires de diverses confessions non seulement traduisent les Écritures dans les langues locales, mais introduisent dans des sociétés traditionnelles plusieurs institutions modernes telles que l'école, l'hopital et l'imprimerie. Ces institutions, alliées à l'entreprise de traduction, constituent les outils de choix du prosélytisme. Le taux de succès est variable. Dans des régions comme l'Orissa, doté d'une forte tradition culturelle et religieuse, il est très faible. Même les éléments de modernité apportés par les missionnaires sont longtemps considérés avec méfiance, en raison de la conjoncture politique qui prévaut dans la région. L'activité missionnaire en Orissa au début du $\mathrm{XIX}^{\mathrm{e}}$ siècle est en effet associée à la domination coloniale. De plus, le sentiment de supériorité culturel et racial des missionnaires leur fait mépriser les conditions et la culture locales. Avec pour conséquence que leurs traductions, qui paraissent ridicules, sont aussitôt rejetées. Si l'Orissa dispose déjà d'une solide tradition en matière de culture littéraire et de traduction, le projet missionnaire contribue cependant à lui insuffler une nouvelle direction et un regain de dynamisme. Quoique les missionnaires aient largement échoué dans leur entreprise d'évangélisation, celle-ci a paradoxalement encouragé longtemps après leur passage le développement d'une culture littéraire et traductive synthétique en Orissa.

Keywords: sub colonialism, cultural coding, translational activism, bhāsā language, oral culture. 
Mots-clés : subcolonialisme, codification culturelle, traduction évangélisatrice, langue $b h \bar{a} s \bar{a}$, culture orale.

Debendra K. Dash: Department of Oriya, Ispat College, Rourkela, District-Sudargarh, Orissa, India

Dipti R. Pattanaik: Department of English, Utkal University, Bhubaneswar-751004, India

Email: diptiranjan1961@yahoo.co.in 